\title{
Results of studies of the influence of phytopreparations on cows and calfs
}

\author{
V.S. Kozyr ${ }^{1}$, P.P. Antonenko ${ }^{2}$, N.I. Suslova ${ }^{2}$, and R.V. Mylostyvyi ${ }^{2, *}$ \\ ${ }^{1}$ Institute of Grain Crops of NAAS, St. V. Vernadsky 14, 49027 Dnipro, Ukraine \\ ${ }^{2}$ Dnipro State Agrarian and Economic University, S. Efremov St. 25, 49600, Dnipro, Ukraine
}

\begin{abstract}
Purpose. To establish the influence of the "Phytochol", "Phytopunk" and "Gastroacide" phytopreparations developed by the authors on the reproductive function of cows, resistance and safety for calves. Methods. Biological, biochemical, hematological, immunological, analytical, biometric, zootechnical. Results. It has been established that in homeopathic doses, the studied drugs are non-toxic, have a wide range of pharmacological effects and contain biologically active substances that have strengthening, tonic properties, metabolism normalizing in the "cowcalf" biochemical system. Conclusions. To normalize the reproductive function of cows, it is advisable to use "Phytochol"and "Phytopunk". The resistance of newborn calves is strengthened by feeding them "Phytopunk" and "Gastroacide". The productivity of young cattle can be increased by introducing the drug "Phytochol" into the ration. The use of phytopreparations "Phytopunk", "Phytochol" in homeopathic doses in cattle breeding contributes to a more efficient management of the industry.
\end{abstract}

\section{Introduction}

In animal husbandry, as in the entire animal kingdom, there are common patterns of development. In the wild, this occurs due to natural selection and reproduction, the best, strongest and healthiest animals, less susceptible to diseases and able to strengthen immunity by self-medication using various herbs and minerals on pastures. All this contributes to increased resistance and preservation of the species. A striking example of this is the Ukrainian Gray breed of cattle, which comes from a wild aurochs (Bos primigenius) and for many centuries transfers to descendants resistance to various environmental and feed conditions [1]. With the cultivation of this genotype and the human desire to use the body more intensively to get more products from it, animals have a number of health and procreation problems. In order not to lose, but to preserve and develop the species and its desired, inherited traits, humanity is improving the technology of breeding, growing and using the livestock, and if necessary, protecting it from diseases. For this, various medications, prophylactic drugs and feed additives are used. Most of them are of chemical and synthetic origin, which often, solving one problem, disrupt the

\footnotetext{
${ }^{*}$ Corresponding author: mylostyvyi.r.v@dsau.dp.ua
} 
homeostasis of the body, as they affect the regulation, and do not correct metabolic processes.

The use of plants for prophylactic and medical purposes has been known since antique times (Hippocrates, Avicenna) has survived to the present day. They show a systemic effect on the body, affect metabolism, adaptation, increased immunity and productivity. Traditional tinctures, decoctions from plant materials are not effective enough, have a short shelf life, do not fully extract biologically active substances, and when boiled, they are destroyed, they also do not have a complex effect. At the same time, according to various authors [2-3], up to $30 \%$ of newborn calves die from non-infectious animal diseases, and $15-20 \%$ of cows do not give offspring.

In this regard, scientists using the healing powers of nature, create new drugs and additives of plant origin, using medicinal herbs, without harming the health of animals. Such herbal preparations include the "Phytopunk", "Phytochol" and "Gastroacide", which we developed, tested on numerous herds and have positively proven themselves as improving the reproductive ability of cows, the resistance of calves and their subsequent meat productivity, which is currently relevant for agricultural units and personal household plots.

\section{Research Methodology}

In the experimental farm "Polivanovka" of the Institute of Grain Crops of the NAAS, three groups of dry Ukrainian gray cows were formed with 14 animals each (analogues by age, live weight (lim. 515-520 kg.) And milk yield), dividing each into two subgroups of control and experimental cows seven animals in each. Animals were kept in the same optimal environmental and feed conditions, their rations were balanced according to their nutritional value according to the norms of detailed livestock feeding [4].

In the preparatory thirty-day period (before the experiment), animals of all groups and subgroups were fed the main ration (MR). The subsequent thirty-day test period, the animals of the control subgroups of each group continued to receive the main ration, and the experimental subgroups in homeopathic doses to the main ration, along with compound feed once a day (in the morning on an empty stomach), were given 10 drops of alcohol tincture dissolved in $100 \mathrm{ml}$ of boiled water (cooled to temperature $37^{\circ} \mathrm{C}$ ). The first group was given "Phytochol", the second - "Phytopunk" and the third - "Gastroacide" within 30 days before calving (experimental scheme). The medicinal herbs that make up these herbal preparations were selected taking into account the pharmacokinetics and pharmacodynamics of the substances they contain, as well as their physicochemical compatibility, which contributed to their synergism in animals.

Table 1. Experimental scheme.

\begin{tabular}{|c|c|c|c|c|}
\hline \multirow[b]{2}{*}{$\begin{array}{l}\text { Groups } \\
\text { (animals) }\end{array}$} & \multirow[b]{2}{*}{$\begin{array}{c}\text { Subgroups } \\
\text { (animals) }\end{array}$} & \multicolumn{2}{|c|}{ Feeding } & \multirow[b]{2}{*}{$\begin{array}{c}\text { Conditions for animals } \\
\text { keeping }\end{array}$} \\
\hline & & $\begin{array}{c}\text { preparatory period } 30 \\
\text { days (first half of } 60 \\
\text { days of dry period) }\end{array}$ & $\begin{array}{c}\text { main period ( } 30 \\
\text { days before } \\
\text { calving) }\end{array}$ & \\
\hline \multirow{2}{*}{$\begin{array}{c}1 \\
(n=14)\end{array}$} & $\begin{array}{l}\text { control } \\
(\mathrm{n}=7)\end{array}$ & MR & MR & \multirow{2}{*}{$\begin{array}{l}\text { the first half of the } \\
\text { experiment - from } 60 \\
\text { days of the dry period } \\
\text { ( } 30 \text { days) of keeping } \\
\text { cows loose on a feed } \\
\text { platform, the second }\end{array}$} \\
\hline & $\begin{array}{l}\text { experimental } \\
\qquad(\mathrm{n}=7)\end{array}$ & MR & $\begin{array}{c}\text { MR+10 drops of } \\
\text { phytochol }\end{array}$ & \\
\hline
\end{tabular}




\begin{tabular}{|c|c|c|c|c|}
\hline \multirow{2}{*}{$\begin{array}{c}2 \\
(n=14)\end{array}$} & $\begin{array}{l}\text { control } \\
(n=7)\end{array}$ & MR & MR & \multirow{4}{*}{$\begin{array}{l}\text { half of the experiment } \\
\text { (30 days) on a leash, } \\
\text { calving in stables, the } \\
\text { front of feeding - } 1.2 \\
\text { m., drinking from } \\
\text { drinking bowls PA- } 2\end{array}$} \\
\hline & $\begin{array}{l}\text { experimental } \\
(n=7)\end{array}$ & MR & $\begin{array}{c}\text { MR+10 drops of } \\
\text { phytopunk }\end{array}$ & \\
\hline \multirow{2}{*}{$\begin{array}{c}3 \\
(n=14)\end{array}$} & $\begin{array}{l}\text { control } \\
(n=7)\end{array}$ & MR & MR & \\
\hline & $\begin{array}{l}\text { experimental } \\
(n=7)\end{array}$ & MR & $\begin{array}{c}\mathrm{MR}+10 \text { drops of } \\
\text { gastroacide }\end{array}$ & \\
\hline
\end{tabular}

The abovementioned herbal preparations were developed by scientists from Dnipro institutes of gastroenterology of the Ministry of Health, Grain crops of the National Academy of Agricultural Sciences and the State Agrarian and Economic University.

"Phytochol" (patent No. 47289) contains $10.4 \mathrm{~g} / \mathrm{l}$ of soluble proteins, $205 \mathrm{mmol} / \mathrm{l}$ of nitrogen, fructose, sucrose, xylose, $\mathrm{pH}-6.5$. It consists of six herbs:

Herba Capsella bursa pastoris, which contains flavonoids (rutin, luteolin, rutinoside), tannins (amines, choline, teramin), saponins, glucosides, organic acids (fumaric, citric, malic, tartaric, ascorbic), microelements, essential oils, potassium compounds. It exhibits a hemostatic, hypotensive, choleretic effect;

Helichrysum arenarium contains flavonoids, glycosides, steroid compounds, fatty acids, fatty oil (cresol), microelements. It has choleretic, diuretic, hemostatic, disinfectant properties;

Mentha piperita is an antispasmodic with analgesic and choleretic action, it contains 1$2.5 \%$ of essential oils (menthol), ursolic, oleanolic, acetic, valerianic acids, tannins;

Valeriana officinalis contains $0.5-2 \%$ of essential oil, borneol, isovalerianic acid, borneol, terpenoids, alkaloids, glucosides, sugars and tannins. It reduces excitability and increases the functional activity of the central nervous system and secretion of the glands of the digestive tract, regulates the work of the heart;

Antropa Belladonnae contains tropane alkaloids (atropine, hyoscyamine, scopolamine), glucosides, scopoletin. It has antispasmodic and anticholinergic properties.

"Phytopunk" (patent No. 48341) is a composition of extracts from seven medicinal plants:

Rheum palmatum contains up to $6 \%$ of anthraglycosides, tannins, tarry and pectin substances, starch, glucose, oxalates, $\mathrm{K}$ and $\mathrm{Ca}$, chrysanolic, malic, gallic and ascorbic acids. It acts as an astringent, anti-inflammatory, and in small doses shows a laxative effect;

Anethum graveoneles - it contains $2.8-4 \%$ of essential oils, flavanoids, $12 \mathrm{mg} / \%$ carotene, folic, nicotinic, menthol acids, salts of $\mathrm{K}, \mathrm{Ca}, \mathrm{P}, \mathrm{Fe}$. Regulates urination, normalizes biochemical processes in the liver, actively suppresses streptococcal and staphylococcal infections, normalizes the cardiovascular system, stimulates the secretion of the gastrointestinal tract, has an anthelmintic effect;

Inula helenium - its chemical composition: polysaccharides (44\% inulin), saponins, 25 $31 \mathrm{mg} / \%$ phylloquinone, 1-3\% essential oil, acetic, fumaric, propionic, ascorbic acid, vitamin E. It has antimicrobial, astringent diuretic and anthelmintic, anti-inflammatory effect;

Menyanthes tritoliata contains glycosides, up to $3 \%$ tannins, essential and fatty oils, choline, resin and fatty acids. Acts as a tonic, choleretic, antiseptic and analgesic; 
Salvia officinalis contains up to $2.5 \%$ of essential oils, alkaloids, flavanoids, tannins, oleanic, ursolic acid, camphor. It has antiseptic, anti-inflammatory, hemostatic effect, strengthens the walls of blood vessels, activates the secretion of the gastrointestinal tract;

Iris germanica contains essential oils, glucoside iridin, astringents, organic acids, fatty oil, starch. It has a disinfectant, anti-inflammatory, enveloping effect;

Conium maculate contains $0.1 \%$ alkaloids, $0.8 \%$ essential oils, caffeic acid, quercetin and kempferol. It has analgesic, anticonvulsant, hemostatic, anticholinergic and hyposecretory effects (in our studies and in practice, hemlock spotted is used in 1,000,000 breeding).

"Gastroacid" (patent No. 49161) is a mixture of herbal tinctures:

Mentha aquatica contains up to $1 \%$ of essential oils, $7 \%$ of tannins, linolenic, linoleic, palmitic, butyric acid, potassium nitrate. It has an antimicrobial property, activates the secretory function of the gastrointestinal tract, has antiallergic, analgesic and choleretic effects;

Hypericum perforatum contains astringents - 10-12\%, flavonoids (hyperoside, rutin), saponins, glycerin - 0.1-0.4\%, essential oil - 0.2-0.3\%, resinous substances - $17 \%$, carotene, ascorbic acid, catechins that contain vitamin $\mathrm{P}$, a small amount of alkaloids. It exhibits anti-inflammatory, antispasmodic, antimicrobial, diuretic properties, reduces capillary fragility and penetration of substances into the intercellular clefts. Flavonoids improve metabolism, increase metabolic processes and improve metabolism and exhibit antihistamine action. Saponins have surface activity and promote the absorption of active substances in the digestive canal, increase the absorption of vitamins, $\mathrm{Ca}, \mathrm{Fe}$ salts and other minerals, normalize cholesterol metabolism;

Glycyrhiza glabra contains saponin glycerisine up to $23 \%$, flavonoids - $27 \%$, sterols, aspargin, coumarins, ascorbic acid $(30 \mathrm{ml} / \%)$. It has antispasmodic, laxative, antiinflammatory and diuretic effects;

Acorus calamus contains up to $5 \%$ of essential oils, glycosides (acorin), $150 \mathrm{mg} / \%$ ascorbic acid, astringents, starch. It has a tonic, anti-inflammatory, analgesic, choleretic, antibacterial and disinfecting effect, improves the secretion of the glands of the gastrointestinal tract;

Coriandrum sativum contains essential oils - $1.5 \%$, tannins, resinous compounds, choline, flavonin up to $0.7 \%$, ascorbic acid. It has an antispasmodic, antibacterial effect, enhances the secretion of the glands of the digestive apparatus, stimulates the regeneration of damaged tissues, is used as a choleretic agent for diseases of the liver and gallbladder;

Pinus sylvestris (pine cones and buds) contains up to $0.36 \%$ of essential oils, astringents, carotene, ascorbic acid, resinous substances - up to $7-12 \%$. It has a choleretic, disinfectant, diuretic, expectorant property;

Centurium erytrae contains up to $1 \%$ alkaloids (gentianin), glucosides (erythurin, erythrocentaurin), essential oils, oleanolic and ascorbic acid, carotenoids. It stimulates the secretion of the glands of the digestive tract, bile secretion, exhibits anti-inflammatory and analgesic effects;

Foeniculum vulgare contains up to $6 \%$ of essential and up to $18 \%$ of fatty oils, protein substances, coumarin, flavanoids, anisic acid. It has anti-inflammatory, secretolytic, antispasmodic, diuretic, choleretic and sedative effects;

Robinia pseudoacacia. Bark, flowers and fruits contain glucosides (robinin), flavonoids, essential oils, sugar, organic acids, trace elements, vitamins. An antispasmodic, antiinflammatory, antihypertensive and hemostatic agent are used. Acacia bark is used for high acidity, stomach and intestinal ulcers and the first stage of hypertension.

All animals involved in the experiment were clinically healthy. During the experiment, adhered to the requirements of the "European Convention for the Protection of Vertebrate 
Animals Used for Experimental and Scientific Purposes" (Strasbourg, 1986), the Law of Ukraine "On the Protection of Animals from Cruelty" No. 3447 of 02.21.2006.

In the blood, the number of red blood cells and leukocytes was studied by Goryaev's camera, hemoglobin by the hemoglobin cyanide method, total protein, total calcium, inorganic phosphorus, reserve alkalinity, and blood serum was determined using a Stat Fox1904 biochemical analyzer (USA). The level of gamma globulins was determined by a turbidimetric method. The principle of the method is based on the fact that phosphate solutions of a certain concentration precipitate protein fractions of blood plasma with the formation of a suspension, the degree of turbidity of which was determined Nephelometric at a wavelength of $590-670 \mathrm{~nm}$. The concentration of immunoglobulins A, G, M - by the method of radial immunodiffusion according to the method of G. Mamcini et al. (1965). The number of $\mathrm{T}$ and $\mathrm{B}$ lymphocytes in the peripheral blood was determined by the method of spontaneous rosette formation. The composition and quality of colostrum was investigated by conventional methods [5]. The total content of immunoglobulins in colostrum was determined using a Kruuse colostrometer (Denmark), using the appropriate instrument scale. Growth indicators (daily average growth, relative growth and coefficient of increase in live weight) in certain age periods of young animals were calculated on the basis of monthly weighings according to the above methods [6].

Mathematical data processing was performed using the built-in statistical functions in the STATISTICA 10 program (StatSoft, Inc., USA). Differences between the samples, determined by the Mann-Whitney U-test (U-test), were considered significant at $\mathrm{P}<0.05$.

\section{Research results}

Throughout the experiment, the animals had normal clinical indicators, body temperature, pulse rate and respiration. The studied drugs are non-toxic, showed a wide spectrum of pharmacological action and contain many alkaloids, macro and microelement glucosides, vitamins, $\mathrm{Na}, \mathrm{K}$ and other biologically active substances (Table 2), which have general strengthening, tonic properties, normalizing metabolism in the biological system "cowcalf".

Table 2. Macro- and microelement composition of phytopreparations, $\mathrm{mg} / \mathrm{l}$.

\begin{tabular}{|c|c|c|c|}
\hline \multirow{2}{*}{$\begin{array}{c}\text { Macro and } \\
\text { microelements }\end{array}$} & \multicolumn{3}{|c|}{ Phytopreparations } \\
\cline { 2 - 4 } & Phytochol & Phytopunk & Gastroacid \\
\hline $\mathrm{Na}$ & 1240 & 7 & 24 \\
\hline $\mathrm{K}$ & 1190 & 560 & 1050 \\
\hline $\mathrm{Cu}$ & 0,154 & 0,130 & 0,197 \\
\hline $\mathrm{Mn}$ & 0,429 & 0,692 & 1,060 \\
\hline $\mathrm{Zn}$ & 0,300 & 0,330 & 1,330 \\
\hline $\mathrm{Pb}$ & 0,433 & 0,01 & 2,133 \\
\hline $\mathrm{Cd}$ & - & - & - \\
\hline $\mathrm{Fe}$ & 0,622 & 0,625 & 0,750 \\
\hline $\mathrm{Ni}$ & 0,185 & 0,093 & 0,195 \\
\hline $\mathrm{Sr}$ & 74,0 & 24,5 & 45,5 \\
\hline $\mathrm{Cr}$ & 0,532 & 0,132 & 0,330 \\
\hline
\end{tabular}

Hematological studies confirm that the use of herbal extracts improves the health status of animals (Table 3 ).

Table 3. Blood counts of cows 10 days after calving, $\bar{X} \pm S \tilde{o}$

\begin{tabular}{|l|c|c|c|c|c|c|c|}
\hline Indicators & \multirow{2}{*}{ units } & \multicolumn{2}{|c|}{ Phytochol } & \multicolumn{2}{|c|}{ Phytopunk } & \multicolumn{2}{c|}{ Gastroacid } \\
\cline { 3 - 7 } & & control & experimental & control & experimental & control & experimental \\
\hline
\end{tabular}




\begin{tabular}{|c|c|c|c|c|c|c|c|}
\hline erythrocytes & $\mathrm{T} / 1$ & $5,2 \pm 0,17$ & $5,5 \pm 0,16^{*}$ & $5,4 \pm 0,13$ & $5,9 \pm 0,21$ & $4,8 \pm 0,17$ & $5,0 \pm 0,29$ \\
\hline leukocytes & $\mathrm{G} / 1$ & $7,8 \pm 0,24$ & $8,1 \pm 0,31^{*}$ & $7,6 \pm 0,38$ & $7,9 \pm 0,19$ & $8,2 \pm 0,31$ & $8,3 \pm 0,42$ \\
\hline Hemoglobin & $\mathrm{g} / 1$ & $102,3 \pm 3,1$ & $106,4 \pm 4,7$ & $99,4 \pm 2,8$ & $105,1 \pm 4,8$ & $96,9 \pm 3,9$ & $99,1 \pm 4,2$ \\
\hline Total protein & $\mathrm{g} / 1$ & $62,3 \pm 1,24$ & $64,8 \pm 2,17$ & $65,1 \pm 3,9$ & $69,3 \pm 1,7$ & $68,7 \pm 3,1$ & $69,6 \pm 2,4$ \\
\hline Total calcium & $\mathrm{mmol} / 1$ & $2,34 \pm 0,05$ & $2,41 \pm 0,08$ & $2,4 \pm 0,07$ & $2,5 \pm 0,11$ & $2,28 \pm 0,09$ & $2,39 \pm 0,14$ \\
\hline $\begin{array}{c}\text { Inorganic } \\
\text { phosphorus }\end{array}$ & $\mathrm{mol} / 1$ & $1,27 \pm 0,03$ & $1,98 \pm 0,04^{*}$ & $1,31 \pm 0,02$ & $1,62 \pm 0,04 *$ & $1,36 \pm 0,05$ & $1,35 \pm 0,06$ \\
\hline Carotene & $\mathrm{mg} / 1$ & $1,41 \pm 0,07$ & $1,47 \pm 0,05$ & $1,39 \pm 0,05$ & $1,44 \pm 0,03$ & $1,53 \pm 0,06$ & $1,54 \pm 0,08$ \\
\hline $\begin{array}{c}\text { Reserve } \\
\text { alkalinity }\end{array}$ & $\mathrm{g} / 1$ & $6,16 \pm 0,04$ & $6,15 \pm 0,07$ & $6,41 \pm 0,09$ & $6,28 \pm 0,06$ & $6,12 \pm 0,09$ & $6,11 \pm 0,05$ \\
\hline
\end{tabular}

* $\mathrm{P}<0,05$ - the significance of the difference between the control and the experimental group

The table shows the changes in the formation of the blood. They are associated with improved hematopoiesis in cows that received phytopreparations. This result is ensured by the best provision of the animal organism with both mineral substances and the formation of a greater number of vitamins and amino acids by microorganisms. In the experimental subgroups of cows, in comparison with control animals, the number of red blood cells increased by $4-9 \%$, white blood cells - by $1-4 \%$ and hemoglobin content - by $2-6 \%$. During the experiment, it was found that due to the use of phytopreparations in the blood of experimental groups of animals, the amount of total protein (1-6\%), Ca (3-5\%), P (24-56\%) and carotene $(1-5 \%)$ increased and a slight decrease in reserve alkalinity $(0.1-2 \%)$, which positively affected the resistance of animals and, especially, newborn young animals. It should be noted that this is more clearly found when feeding "Phytochol" and " Phytopunk". Although "Gastroacide" had a positive effect on the stabilization of their homeostasis.

Gynecological studies showed (Table 4) that in the experimental subgroups calving of cows was normal without obstetrics, there was no detention and separation of the placenta, timely processes of involution of the uterus and ovaries, the service period did not exceed 65 days. At the same time, in animals of the control subgroups, there was some deviation from the physiological norm (subinvolution of the uterus and retention of the placenta). In yield of calves per 100 cows, they were inferior to experimental animals by $14 \%$.

Table 4. The effect of herbal remedies on the reproductive function of cows, and the composition of colostrum.

\begin{tabular}{|c|c|c|c|c|c|c|c|}
\hline \multirow[t]{2}{*}{ Indicators } & \multirow{2}{*}{ units } & \multicolumn{2}{|c|}{ Phytochol } & \multicolumn{2}{|c|}{ Phytopunk } & \multicolumn{2}{|c|}{ Gastroacid } \\
\hline & & control & $\begin{array}{c}\text { experime } \\
\text { ntal }\end{array}$ & control & $\begin{array}{c}\text { experime } \\
\text { ntal }\end{array}$ & control & $\begin{array}{c}\text { experime } \\
\text { ntal }\end{array}$ \\
\hline Inseminated cows & animals & 7 & 7 & 7 & 7 & 7 & 7 \\
\hline $\begin{array}{l}\text { Fertilization of } \\
\text { Cows }\end{array}$ & $\%$ & 5 & 7 & 6 & 7 & 5 & 7 \\
\hline Live calves born & animals & 5 & 7 & 6 & 7 & 5 & 7 \\
\hline $\begin{array}{l}\text { Postpartum } \\
\text { Problems }\end{array}$ & animals & 1 & - & 1 & - & 2 & - \\
\hline $\begin{array}{l}\text { The output of } \\
\text { calves per } 100 \\
\text { cows }\end{array}$ & animals & 85,7 & 100 & 85,7 & 100 & 86,0 & 100 \\
\hline $\begin{array}{l}\text { Lactation milk } \\
\text { yield }\end{array}$ & $\mathrm{kg}$ & 5200 & 5180 & 5125 & 5135 & 5310 & 5302 \\
\hline $\begin{array}{l}\text { Colostrum } \\
\text { Composition: }\end{array}$ & & & & & & & \\
\hline $\begin{array}{l}\text { Total protein } \\
\text { first milk yield }\end{array}$ & $\mathrm{g} / 1$ & $\begin{array}{l}183 \pm 7,2 \\
159 \pm 2,4 \\
\end{array}$ & $\begin{array}{l}200 \pm 6,1^{*} \\
186 \pm 2,2 *\end{array}$ & $\begin{array}{l}185 \pm 6,5 \\
165 \pm 1,8 \\
\end{array}$ & $\begin{array}{c}205 \pm 8,5 \\
189 \pm 2,0^{*}\end{array}$ & $\begin{array}{l}188 \pm 7,4 \\
163 \pm 3,4 \\
\end{array}$ & $\begin{array}{l}206 \pm 8,1 \\
165 \pm 3,8 \\
\end{array}$ \\
\hline
\end{tabular}




\begin{tabular}{|l|l|l|l|l|l|l|l|}
\hline second milk yield & & & & & & \\
\hline $\begin{array}{l}\text { Immunoglobulins } \\
\text { first milk yield } \\
\text { second milk yield }\end{array}$ & $\mathrm{g} / 1$ & $\begin{array}{c}55 \pm 2,3 \\
45 \pm 0,9\end{array}$ & $\begin{array}{c}65,1 \pm 1,8 \\
* \\
52,9 \pm 1,5 \\
*\end{array}$ & $\begin{array}{c}48 \pm 1,8 \\
32 \pm 1,0\end{array}$ & $\begin{array}{c}60 \pm 2,3^{*} \\
40 \pm 2,4^{*}\end{array}$ & $\begin{array}{c}58 \pm 2,0 \\
39 \pm 3,1\end{array}$ & $\begin{array}{c}61 \pm 3,8 \\
42 \pm 2,9\end{array}$ \\
\hline $\begin{array}{l}\text { Titrated acidity } \\
\text { first milk yield } \\
\text { second milk yield }\end{array}$ & & $\begin{array}{c}49 \pm 0,9 \\
41 \pm 1,2\end{array}$ & $\begin{array}{c}43 \pm 1,0^{*} \\
37 \pm 0,7^{*}\end{array}$ & $\begin{array}{c}52 \pm 1,4 \\
42 \pm 1,0\end{array}$ & $\begin{array}{c}44 \pm 0,5^{*} \\
35 \pm 1,0^{*}\end{array}$ & $\begin{array}{c}50 \pm 0,7 \\
39 \pm 1,4\end{array}$ & $\begin{array}{c}46 \pm 1,1^{*} \\
38 \pm 0,9\end{array}$ \\
\hline
\end{tabular}

* $\mathrm{P}<0,05$ - the significance of the difference between the control and the experimental group

In the colostrum of the first and second milk yield of cows in the experimental subgroups, in comparison with the control animals, the total protein content increased on average by 10 and $11 \%$, the content of immunoglobulins - by 13 and $17 \%$, titrated acidity decreased by 12 and $10 \%$, respectively. In our opinion, phytopreparations provide a greater supply of nutrients to the mammary gland of cows. Confirmation of this is an increase in the synthesis of total protein and immunoglobulins in the udder of cows, which enter the colostrum. The increased intake of nutrients, in turn, affected the decrease in titrated acidity of colostrum of the first and second milk yield.

The phytopreparations "Phytochol" and "Phytopunk" were more effective, which over the course of a further long period contributed to the preservation of the health of cows and the genetic potential of productivity and to obtain full offspring from them.

Improving the metabolic state of cows receiving phytopreparations also affected the state of the fetus during the late stage of fetal development. Calves that received the best colostrum in their composition contained higher values of morphological and biochemical parameters in the blood, as well as lymphocytes and certain classes of immunoglobulins. In particular, hematological indicators of calves (Table 5) indicate a positive effect of phytopreparations on the physiological status of animals.

Table 5. Blood counts of calves 10 days of age.

\begin{tabular}{|l|c|c|c|c|c|c|c|}
\hline \multirow{2}{*}{ Indicators } & \multirow{2}{*}{ units } & \multicolumn{2}{|c|}{ Phytochol } & \multicolumn{2}{c|}{ Phytopunk } & \multicolumn{2}{c|}{ Gastroacid } \\
\cline { 3 - 8 } & & control & experimental & control & experimental & experimental & experimental \\
\hline erythrocytes & $\mathrm{T} / 1$ & $4,7 \pm 0,16$ & $5,2 \pm 0,21^{*}$ & $5,1 \pm 0,12$ & $5,6 \pm 0,33^{*}$ & $4,5 \pm 0,12$ & $4,8 \pm 0,21$ \\
\hline leukocytes & $\mathrm{G} / 1$ & $7,3 \pm 0,48$ & $8,6 \pm 0,54$ & $7,9 \pm 0,20$ & $8,4 \pm 0,14$ & $7,9 \pm 0,27$ & $8,1 \pm 0,33$ \\
\hline Hemoglobin & $\mathrm{g} / 1$ & $95,4 \pm 2,2$ & $101,6 \pm 4,2$ & $98,4 \pm 6,1$ & $107,6 \pm 3,2$ & $102,8 \pm 4,6$ & $104,2 \pm 3,5$ \\
\hline Total protein & $\mathrm{g} / 1$ & $66,4 \pm 2,2$ & $72,7 \pm 1,3^{*}$ & $67,0 \pm 3,2$ & $78,5 \pm 2,8^{*}$ & $65,9 \pm 4,1$ & $68,7 \pm 4,8$ \\
\hline Total calcium & $\mathrm{mmol} / 1$ & $0,23 \pm 0,04$ & $0,28 \pm 0,01$ & $0,22 \pm 0,01$ & $0,29 \pm 0,02^{*}$ & $0,22 \pm 0,03$ & $0,26 \pm 0,03$ \\
\hline $\begin{array}{l}\text { Inorganic } \\
\text { phosphorus }\end{array}$ & $\mathrm{mol} / 1$ & $0,12 \pm 0,01$ & $0,17 \pm 0,02$ & $0,11 \pm 0,02$ & $0,15 \pm 0,01^{*}$ & $0,14 \pm 0,04$ & $0,15 \pm 0,02$ \\
\hline Carotene & $\mathrm{mg} / 1$ & $0,32 \pm 0,04$ & $0,44 \pm 0,01^{*}$ & $0,28 \pm 0,02$ & $0,35 \pm 0,04$ & $0,31 \pm 0,03$ & $0,33 \pm 0,05$ \\
\hline $\begin{array}{l}\text { Reserve } \\
\text { alkalinity }\end{array}$ & $\mathrm{g} / 1$ & $6,37 \pm 0,09$ & $6,21 \pm 0,08$ & $6,40 \pm 0,08$ & $6,29 \pm 0,11$ & $6,36 \pm 0,06$ & $6,31 \pm 0,09$ \\
\hline
\end{tabular}

* $\mathrm{P}<0,05$ the significance of the difference between the control and the experimental group

In the blood of the experimental groups, in comparison with the control, the number of erythrocytes (by 7-11\%) and leukocytes (3-18\%) increased, the content of hemoglobin (1$9 \%$ ) increased, total protein (4-17\%) increased, total calcium (18-32\%) increased and inorganic phosphorus (7-42\%) increased, carotene (6-37\%) increased. Reserve alkalinity decreased by $1-3 \%$. Fluctuations in all blood parameters of experimental calves were within the physiological norm. 
A study of the immune state of the body of newborn animals indicates the positive effect of phytopreparations on the stimulation of humoral and cellular factors of the body's defense (Table 6).

Table 6. Immunological blood counts of calves 10 days of age.

\begin{tabular}{|l|c|c|c|c|c|c|c|}
\hline \multirow{2}{*}{ Blood counts } & \multirow{2}{*}{ units. } & \multicolumn{2}{|c|}{ Phytochol, $\mathrm{n}=7$} & \multicolumn{2}{c|}{ Phytopunk, $\mathrm{n}=7$} & \multicolumn{2}{c|}{ Gastroacid, $\mathrm{n}=7$} \\
\cline { 3 - 7 } & & control & experimental & control & experimental & control & experimental \\
\hline Gamma globulins & $\mathrm{g} / 1$ & $16,3 \pm 0,31$ & $20,4 \pm 0,2^{*}$ & $17,1 \pm 0,5$ & $20,1 \pm 0,7^{*}$ & $16,0 \pm 0,8$ & $17,3 \pm 0,3$ \\
\hline Immunoglobulins & & & & & & & \\
\hline $\mathrm{G}$ & $\mathrm{g} / 1$ & $14,1 \pm 0,12$ & $16,8 \pm 0,2^{*}$ & $14,7 \pm 0,4$ & $16,7 \pm 0,2^{*}$ & $13,9 \pm 0,4$ & $13,7 \pm 0,2$ \\
\hline $\mathrm{M}$ & $\mathrm{g} / 1$ & $1,3 \pm 0,07$ & $1,9 \pm 0,03^{*}$ & $1,5 \pm 0,1$ & $1,9 \pm 0,1^{*}$ & $1,3 \pm 0,01$ & $1,9 \pm 0,05^{*}$ \\
\hline A & $\mathrm{g} / 1$ & $0,9 \pm 0,02$ & $1,7 \pm 0,03^{*}$ & $0,9 \pm 0,1$ & $1,5 \pm 0,1^{*}$ & $0,8 \pm 0,04$ & $1,7 \pm 0,09^{*}$ \\
\hline T- lymphocytes & $\%$ & $26,0 \pm 0,9$ & $42,5 \pm 1,1^{*}$ & $27,6 \pm 1,4$ & $41,1 \pm 2,4^{*}$ & $29,4 \pm 0,7$ & $30,8 \pm 1,4^{*}$ \\
\hline B- lymphocytes & $\%$ & $7,1 \pm 0,13$ & $11,0 \pm 0,2^{*}$ & $7,7 \pm 0,3$ & $9,3 \pm 0,4^{*}$ & $8,1 \pm 0,18$ & $8,6 \pm 0,23$ \\
\hline
\end{tabular}

* $\mathrm{P}<0,05$ - the significance of the difference between the control and the experimental group

In the blood of calves of the experimental groups under the influence of "Phytochol" and "Phytopunk", the content of gamma globulins increased by $17-25 \%$, class G immunoglobulins - by $14-19 \%$, class $\mathrm{M}$ - by $27-46 \%$ and class A - by $67-89 \%$. The level of T- and B-lymphocytes increased by $49-63$ and $20-55 \%$, respectively. At the same time, "Gastroacide" had a less pronounced immunomodulating effect on the animal organism.

Marked changes in calves blood counts may be due to a higher ability of their body to absorb colostrum nutrients. The reason for this may be the best level of digestive system development in animals that were under the influence of the positive effects of the drug in the prenatal period.

Antigenic stimulation of mother cows during pregnancy and, as a consequence, an increase in the immunological status of newborn calves, had a positive effect on the growth, development and preservation of calves (Table 7).

Table 7. Growth and preservation of calves.

\begin{tabular}{|c|c|c|c|c|c|c|c|}
\hline \multirow[t]{2}{*}{ Indicators } & \multirow{2}{*}{ units } & \multicolumn{2}{|c|}{ Phytochol, n=7 } & \multicolumn{2}{|c|}{ Phytopunk, n=7 } & \multicolumn{2}{|c|}{ Gastroacid, $n=7$} \\
\hline & & control & experimental & control & experimental & control & experimental \\
\hline $\begin{array}{l}\text { Live birth } \\
\text { weight } \\
\text { at age }\end{array}$ & $\mathrm{kg}$ & $27,9 \pm 0,3$ & $28,1 \pm 0,6$ & $28,7 \pm 0,45$ & $28,3 \pm 0,44$ & $29,1 \pm 0,2$ & $29,3 \pm 0,5$ \\
\hline 6 months & $\mathrm{kg}$ & $189 \pm 3,1$ & $188 \pm 2,4$ & $184 \pm 0,9$ & $185 \pm 1,0$ & $186 \pm 3,1$ & $188 \pm 2,0$ \\
\hline $\begin{array}{l}\text { Average daily } \\
\text { gain for the } \\
\text { period }\end{array}$ & & & & & & & \\
\hline $0-6$ months & $\mathrm{g}$ & $880 \pm 11,3$ & $874 \pm 7,4$ & $846 \pm 6,3$ & $855 \pm 4,6$ & $857 \pm 9,1$ & $867 \pm 12,6$ \\
\hline $6-12$ months & g & $831 \pm 3,2$ & $956 \pm 5,4^{*}$ & $768 \pm 2,9$ & $806 \pm 6,2 *$ & $765 \pm 10,4$ & $770 \pm 4,2$ \\
\hline
\end{tabular}

* $\mathrm{P}<0,05$ - the significance of the difference between the control and the experimental group

Under the influence of "Phytochol" and "Phytopunk" in young experimental groups during the period of maximum formation of meat qualities (12-18 months), live weight 
increased by $6-9 \%$ with an increase in average daily growth from 2 to $15 \%$. "Gastroacide" had a less pronounced effect on calf growth energy, although its tendency was positive. In all cases, the use of herbal remedies had a positive effect on the safety of calves, which increased by $13-25 \%$.

\section{Discussion}

It is known that the health of parents largely determines the viability of offspring [7]. However, the resistance and safety of newborn calves is also due to other factors, especially fodder [8]. Our studies confirm that the use of the author's preparations "Phytochol", "Phytopunk" and "Gastroacide" strengthens the immunity of animals, increases the body's resistance to some deviations from the norm of the external environment when growing them, and, first of all, feeding conditions, since only natural feed in conditions of the steppe zone of Ukraine it is almost impossible to provide a balanced ration of animals.

Violation of the reproductive ability of the broodstock leads to significant repeating of cows and to shortage of calves. The creation of the studied drugs is aimed precisely at balancing rations by replenishing the missing stimulants of the sexual function of animals, as a reaction of the body to antigenic stimulation during pregnancy. The use of herbal remedies 30 days before calving contributed to an increase in the morpho-biochemical parameters of the blood of cows, the normalization of labor and the restoration of the reproductive organs of cows in the postpartum period. In this regard, the phytopreparations "Phytochol" and "Phytopunk" proved to be more effective, which, over a long period of time, contributed to the preservation of cows health, genetic productivity potential and to obtain full offspring from them.

Studies have established [9] that "Phytochol" has a positive effect on metabolism in the liver, provides improved hepatocyte function, microcirculation and reparative processes in it, and exhibits high immunostimulating activity, anti-inflammatory and tonic effect. When it was tested, the recovery period was reduced three times and the death of calves was halved, their average daily gain in live weight increased by $17-18 \%$.

Feeding cows "Phytopunk" 30 days before calving had a positive effect on the quality of colostrum and the physiological condition of calves. In the colostrum of cows of the first and second milk yield, the content of total protein and immunoglobulins increased, which positively affected the physiological state of the calf's body and their growth energy [10]. The results of the study allow us to confirm the possibility of reducing the incidence (and death) of calves, increasing the resistance of their body against infectious agents due to immune stimulation of pregnant cows and the importance of immune colostrum in protecting young animals during the most critical period of their life. Thus, the data presented contribute to increasing the productive longevity of cows and anti-infectious protection of their offspring.

Gastrointestinal diseases in newborn calves, as a rule, arise with dysfunction of the neurohumoral mechanisms of bile formation and biliary excretion. Young animals in the postnatal period most often die from low immunity and diseases of various etiologies. Among the causes [11] that lead to the death of young animals is mostly a non-contagious pathology (up to 90\%), and in half of the cases in calves 10-15 days of age, $80 \%$ of them in the colostrum due to digestive upset. Previous studies show [12] that the use of "Gastroacide" in practice reduced the incidence of newborn young animals by $40 \%$ and increased their safety by $20 \%$, they have improved metabolism, general condition, and increased resistance (increase in live weight).

In young animals obtained from experimental subgroups of cows, metabolic disorders, signs of dyspepsia and other gastrointestinal diseases were not established, since in the 
neonatal period it was possible to exclude immunodeficiency conditions that cause high economic damage to agroformations [13].

Phenotypic indicators depend not only on heredity, but also on environmental conditions. The better the living conditions of the young, the higher its productivity. But, under production conditions, this is not always possible to ensure. There are many reasons for this and they are different [14]. Recommended drugs contribute to some solution to this problem by mobilizing the calf's body reserves to maintain safety and increase the gain in live weight of calves.

We believe that the mechanism of the versatile influence of author's phytopreparations in homeopathic doses is due to their holographic information-energy action in the animal organism, which is a nonlinear factor with similar holographic properties that assimilates their medical form by the principle of summation. This explains their influence on all body systems, normalizing its bioenergy [15]. This is confirmed by numerous reports on the positive effect of biologically active substances included in medicinal plants (anthraquinones, anthrons, stilbenes, flavonoids, acylglycosides, pyrons, etc.), which have anti-inflammatory, antimicrobial, antifungal, hepatoprotective and immunomodulating effects [16-17].

\section{Conclusions}

Based on the research, the following conclusions can be drawn:

1. To normalize the reproductive function of cows, it is advisable to use "Phytochol" and "Phytopunk".

2. The resistance of newborn calves is strengthened by feeding them "Phytopunk" and "Gastroacide".

3. The productivity of young cattle can be increased by introducing "Phytochol" into the ration. The use of phytopreparations " Phytopunk", " Phytochol" in homeopathic doses in cattle breeding contributes to a more efficient management of the industry.

\section{References}

1. Z.Y. Shcherbatyj, O.V. Kozenko, V.Y. Bodnaruk, L.I. Muzyka, A.J. Zhmur, T.V. Orikhivskyy, Scientific Messenger of LNU of Veterinary Medicine and Biotechnologies. Series: Agricultural Sciences, 18(1), 173-176 (2016)

2. S. Kasap, E.M. Temizel, G. Akgul, S. Senturk, Journal of Harran University Faculty of Veterinary Medicine, 7(1), 102-107 (2018) doi:10.31196/huvfd.470976

3. I.M.G.A. Santman-Berends, Y.H. Schukken, G. van Schaik, Journal of Dairy Science (2019) doi:10.3168/jds.2019-16381

4. A.P. Kalashnikov, I.I. Kleymenov, V.N. Bakanov, Norms and diets of farm animals feeding, 352 (Moscow, 1985)

5. S.I. Tsekhmistrenko, O.I. Kononskyi, Biochemistry of milk and milk products, 168 (Bila Tserkva, 2014)

6. T.V. Pidpala, Livestock and technology for the production of milk and beef, 369 (Vydavnychyi viddil MDAU. Mykolaiv, 2007)

7. J. Mee, Animals, 3(4), 1036-1057 (2013) doi:10.3390/ani3041036

8. O.M. Chernenko, O.I. Chernenko, R.A. Sanjara, Regulatory Mechanisms in Biosystems, 8(2), 299-303 (2017) https://doi.org/10.15421/021747 
9. N. Suslova, P. Antonenko, N. Makeyeva, O. Strah, Naukovyi visnyk veterynarnoi medytsyny, 2 (119), 22-24 (2015)

10. V.S. Kozyr, P.P. Antonenko, R.V. Mylostyvyi, N.I. Suslova, P.M. Skliarov, , O.P. Reshetnychenko, T.D. Pushkar, V.O. Sapronova, O.M. Pokhyl, Theoretical and Applied Veterinary Medicine, 7(3), 137-142 (2019) doi:10.32819/2019.71024

11. L.E. Hulbert, S.J. Moisá, Journal of Dairy Science, 99(4), 3199-3216 (2016) doi:10.3168/jds.2015-10198

12. P.P. Antonenko, N.I. Suslova, E.A. Panasenko, Jivotnovodstvo i veterinarnaya meditsina, 2 (25), 47-53 (2017)

13. J. Wilm, J.H.C. Costa, H.W. Neave, D.M. Weary, M.A.G. von Keyserlingk, Journal of Dairy Science, 101(7), 6430-6436 (2018) doi:10.3168/jds.2017-13553

14. A. Phipps, D. Beggs, A. Murray, P. Mansell, M. Pyman, Australian Veterinary Journal, 96(4), 107-110 (2018) doi:10.1111/avj.12686

15. R. Bhikha, American Journal of Internal Medicine, 6(5), 99 (2018) doi:10.11648/j.ajim.20180605.13

16. Y.-J. Cao, Z.-J. Pu, Y.-P. Tang, J. Shen, Y.-Y. Chen, A. Kang, G.-S. Zhou, J.-A. Duan, Chinese Medicine, 12(1), (2017) doi:10.1186/s13020-017-0158-5

17. K.K. Chahal, A. Monika, Kumar, U. Bhardwaj, R. Kaur, Journal of Pharmacognosy and Phytochemistry, 6(2), 295-306 (2017) http://www.phytojournal.com/archives/ 2017/vol6issue2/PartF/6-2-67-817.pdf 